\title{
ON THE RELATIONSHIP BETWEEN THINKING AND WORLD LANGUAGE MODELING: BASED ON OLD ARMENIAN LANGUAGE MATERIALS
}

\begin{abstract}
The analysis of the issues concerning the relationship between thinking and world language modelling showcases that linguistic modellings are at the forefront of the Old Armenian language and regulate the linguistic determinism and linguistic outlook of the society. Examinations of the Old Armenian sentence models and samples reveal that various qualitative manifestations of thinking existed in the $5^{\text {th }}$ century, which are conditioned by the grammatical structure of Old Armenian, and the foreign-language influences. These were displayed both in translated literature and independent bibliographic works. Linguistic determinism as a synchronous maxim can also bear the stamp of foreign-language influences while genuinely preserving the peculiarities of national mentality.
\end{abstract}

Keywords: linguistic determinism, linguistic consciousness, linguistic outlook, maxim, linguistic symbol, language modelling, syntactic model.

The world is reflected in the consciousness of an individual through the symbolistic system of language. While the content of linguistic symbol is conditional, it is understandable for the native linguistic community. Word (partial symbol) and form (semi symbol) are linguistic symbols that are used in speech in sentence phrase and content. In this case, a sentence is considered to be a full linguistic symbol within which appear all the other linguistic features exhibiting diverse grammatical relationships towards each other (Kodukhov, 2013, p. 132). The sentence is the supreme form of language meaning modelling, which fully reflects all degrees of linguistic determinism (conscious action). ${ }^{1}$

In fact, the dependence of language and thinking is more vivid and is largely manifested in natural language. The semantics of the scientific language seeks as much independence as possible from the linguistic means, whereas the language of argument includes
Unlike the accepted approaches to thinking in philosophy and logic, here, (in philosophy thinking is actions of an individual aimed at rational cognition of the world, and in logic it is reasoning the components of which are concept, judgment, and inference), thinking is defined as the way we understand the things, phenomena, and the meaning of their connections and relationships existing in the world, that come to us through the linguistic membrane, in other words, coded signs.

Philosopher P. Kopnin (1968, p. 25) defines the concept of language as a form of knowledge

linguistic expressions, structures, and wordstrips typical of rhetorical speech (Hovhannisyan, 2009, p. 151; Hovhannisyan, 2017). Similar observations can be made in terms of language of science as well. Eventually, the language of science is developed on the basis of the natural language; however the examination of this issue is beyond the scope of the article. 
that exists as a sign system. That's why knowledge is always as a language.

As noted by St. Chase, all the higher levels of thinking depend on the language (Whorf, 1966, p. VI). This observation stems from the primary role of the language in the context of language and thinking interrelation. The SepirWarf hypothesis is based on this theory, according to which thinking (consciousness) is dependent on language and is conditioned by language. In other words, people's thinking, worldview, and maxim are shaped by the content, structure and nature (Brutian, 1972 ${ }^{\text {a }}$; Brutian, 1972 , pp. 41-50; "Linguistic Encyclopedic Dictionary", 1990, p. 443) of a language.

Issues related to language and thinking have been studied by a number of philosophers, psychologists, linguists, and other specialists. In this field, the theory of expression of the conceptual system and the linguistic meaning developed by P. Pavilyonis is highly acceptable. According to the theory, the meaning of linguistic expressions includes both the fundamental concepts of concept construction and the possibilities of constructing a certain "world map" (Pavilenis, 1983, p. 207).

In this regard, the representatives of the Moscow Psychological School have developed the content model of consciousness known as linguistic consciousness. Language consciousness is a scientific structure, a component of consciousness in which content is modelled on the basis of the individual's word combinations and verbal response (Pishchalnikova \& Sonin, 2017, p. 147; Tarasov, 2000, pp. 3-4).

Thinking and linguistic consciousness are interconnected and conditioned by one another.

If on the one hand we accept the primary function of thinking, in case of a separate language and on the other hand the principle of determining the structure of mentality of language, we can say that the examination of the structure of Old Armenian, in particular, the linear model of the sentence, shows that we are dealing with different qualitative manifestations of thinking which are conditioned by the grammatical structure of Old Armenian, and the foreign-language influences displayed both in translated literature and independent bibliographic works.

The actual sentence structure analysis of different types of sentences in Old Armenian language shows that there are two trends in linguistic tactics in such language.

The first sentence structure is the model formed by foreign-language influences, which is particularly reflected in the translation literature and as a result of authentic literature. The second structure is the type of sentence (therefore, thinking), which is considered as one of the foundations of modern linguistics, perhaps the most important one. The classical syntactic models formed as a result of foreign-language influences have been manifested in the linguisticstylistic system of translated literature. By examining the syntactic models and patterns of sentences in Old Armenian translations, one can draw on the key issues of the fifth-century Armenian system linguistic determinism (Hayrapetyan, 2005).

This particularly applies to the language of the Bible.

The free or literal nature of Bible translations has also been expressed in the syntax. Despite the fact that amongst translations of the classic period, the Bible is remarkable in its accuracy, it has been proved by E. F. Rhodes, that there are a lot of sentences in the New Testament reproduce the Greek syntax, with some restrictions (Muradyan, 2010, p. 207). 
The study of the Bible's linguistic determinism can be anchored on the model sentences of translation books to showcase the level of foreign-language impact on national, linguistic determinism.

When conducted such examinations, it is vital to categorize the main and secondary parts of a sentence, the relationship of which implies and imposes the sentence structure as a syntactical-linear unit. Jahukyan (1989, p. 158) used the concepts of nuclear and near-nuclear parts to characterize compound words (root and derivative). In the syntactical-line the position, order and syntactic features of the sentence parts are acclimatized by linguistic determinism: the sentence brings the information bearer to the foreground, making it a substantial, primary unit, followed by members which interpret and complement its meaning.

For example, consider the following phrase from the Bible's Book of Proverbs: The proverbs of Solomon, son of David, king of Israel.

This sentence structure or such syntactic models are typical to Old Greek language from which the Bible was translated into Armenian. Though this type of sentence structures in Armenian originated as a result of the foreign-language influence, nevertheless, this syntactic model is quite common in Old Armenian manuscripts. In the given case, the word "proverbs" (umulp) is the main word, the nuclear part, of the sentence that is the centre of the communication unit and the linguistic symbol that carries the information. This sentence model demonstrates the peculiarities of linguistic determinism, according to which the primary importance is given to the content of the key member(s), followed by members interpreting its meaning with interdependent relationships.
The uniqueness of this sentence model lies within the fact that each subsequent sentence part complements the previous one expressing various grammatical (dependent) relations: the word Solomon (Unทninu) is the specifier of the

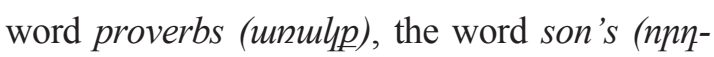
zij) is the apposition of the word Solomon (Unqninu), the word David's (J.muph) is the apposition of the word son's (nnqun), the word king (puquinn) is the attribute of the word David's (2-muph), the word Israel's (Funujkhh) is the specifier of the word king's (puquinnh). According to the linguistic determinism of Old Armenian, the order of the parts of this sentence is as follows: $1,2,3,4,5,6 .^{2}$

This sentence model, as well as its equivalent model of linguistic determinism, is widespread in the independent manuscripts of Old Armenian. This fact can be considered a consequence of the Bible translation, probably one of the earliest manifestations of Greek influence. However, Muradyan (2010, p. 201) notes that the translation of the Bible is of classical nature, in which the linguistic influence of Greek was minimal.

It should be noted that the language Greek influenced the linguistic model is absolutely not displayed as a unique sentence model. Language

2 This syntactic sentence model is typical to Ancient Greek. It matches with Latin, Russian, English, Ger-

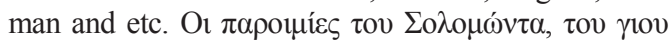

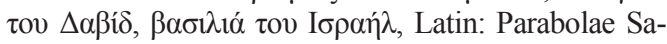
lomomis filii David regis Israhel, Russian: Притчи Саломона сына Давида царя Израеля, English: The Proverbs of Salomon, son of Davit, King of Israel, German: Die Fabeln von Salomon des Sohns israelischen Königs David.

It should be noted that the same sentence in modern Armenian has absolutely reverse syntax, which testifies the peculiarity of modern linguistic determinism. Compare: Isreal king's, David's son's, Solomon's proverbs. - The proverbs of Solomon son of David, king of Israel. (Fupuluh puquinn T.unlph

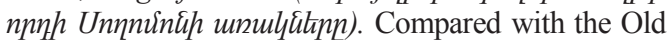
Armenian, the sequence of the contemporary Armenian sentence model is $6,5,4,3,2,1$. 
examination of the Bible shows that Greek (Philhellenic) style, in terms of syntax, is not specific to all of its books.

The syntactic sentence models of the translated books of the Bible mostly correspond to the linear structure of the sentences of the literary works in Armenian. However, in the Armenian self-regulating literary works (dogmatic, apologetic, historical, hagiographical, philosophical, etc.) the Greek style is mixed with Old Armenian syntactic models.

\section{Comparisons:}

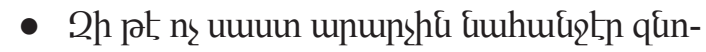

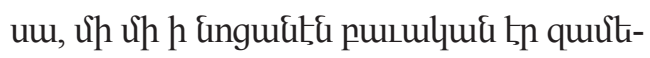

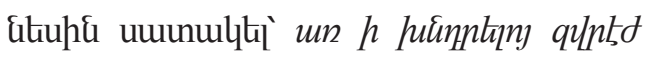

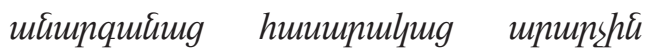
(bqu., 16): [If the Creator's anger did not conflict with them, one of them would be enough to exterminate all and to take revenge on the dishonour of the Creator of the universe (Eznik of Kolb, 1826, p. 16).]

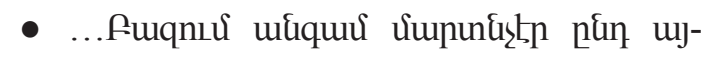

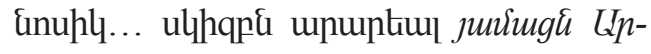

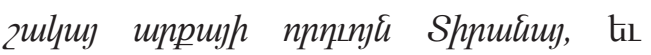

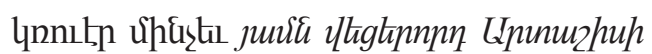

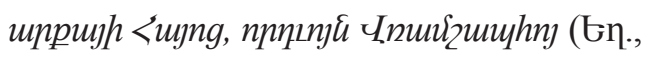
6): [Many times he has fought against them... starting from the beginning of the kingdom of Arshak the son of Tiran, until the sixth year of the reign of Vramshapuh's son, the King Artashes (Eghishe, 1957, p. 6).]

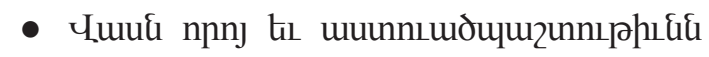
punănuqinı|a qưưulupnıptiuúp tiplıtith hishn juzhumphis <ujng, h ulqpuing

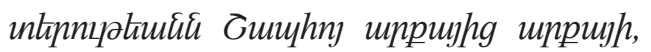

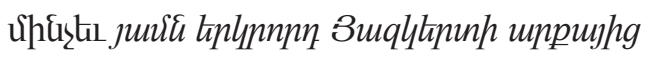

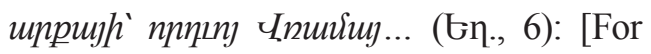
this reason, Christianity explicitly adored the King of Armenian Kingdom from the beginning of the King Shapuh's reign until the second year of the reign of Vram's son, the King of King Hazkert (Eghishe, 1957, p. 6).]

- hul fbí... hnцpujn huuuditi h uuh-

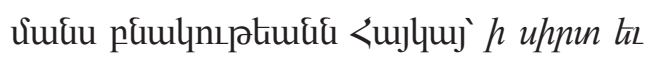
h vimnihu vumwhughul unwing qonuinnmg (łunn., 34): [And Bel...was hurrying to reach the borders of Hayk's residence, relying on the strength and courage of his powerful men (Khorenatsi, 1913, p. 34).]

These syntactic models gradually engage with the grammatical (syntactic) system of the Old Armenian language and act as shared manifestations of linguistic determinism.

Now, let's discuss the type of manifestation of Old Armenian language on which the modern linguistic determinism model is based.

The examination of the sentence models of Old Armenian manuscripts from the classical and post-classical time periods shows that the Armenian linguistic determinism portrayed in the independent manuscripts slightly differs from the syntactic models of Bible translations.

The point is that almost all Bible translations into European languages preserved the Greek syntax. Old Armenian and European languages, including Old Greek, have common types of the form and syntax, so they have preserved the translation tradition by adapting the language of the translation to the models of linguistic determinism of the original language.

Along with the importance of preserving the syntactic models of the original language and the syntax of translated languages, conservation of traditions was also an essential factor. On the other hand, a tradition, in its turn, can form corresponding linguistic determinism, which is partly manifested in the Old Armenian manuscripts. 
In his book devoted to syntax, the Greek gospels and their Gothic, Armenian and Old Slavonic translations, G. Cuance showed through concrete examples that the Greek language syntactic influence on this or that sentence model is conditioned only by the internal logic of Armenian language (Muradyan, 2010, p. 203).

The fifth-century historians' language analysis shows that sensible keyword of a sentence is not always syntactically positions in the foreground: the subject and predicate can be followed by attributes. Such sentence structures and patterns do not correspond to the world's linguistic and philosophical perceptions.

Even a subtle observation of the syntactic models of the following original writings may give some idea of the 5th-century linguistic determinism. Compare:

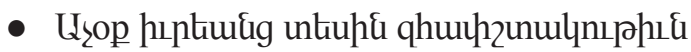
upunng hıptiuigg, tiı ulquigop hıpliuing

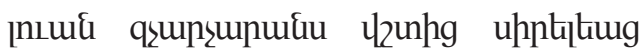

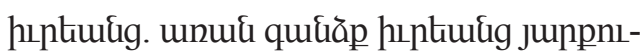

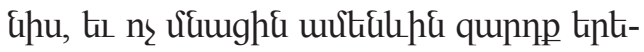
uug hцltuulg (Gn., 201): [They witnessed the plunder of their possessions and hear the sufferings of their loved ones: their ornaments were seized for the needs of the kingdom, and no ornaments were left on their faces (Eghishe, 1957, p. 201).]

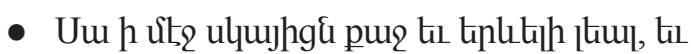

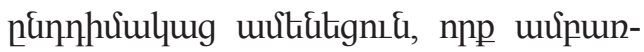

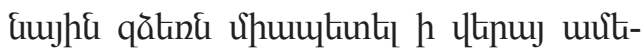

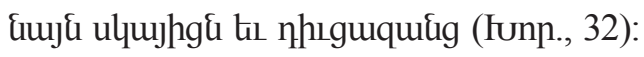
[This man was brave and well-known amongst the giants and turned against all those who tried to gain control over all the giants and the heroes (Khorenatsi, 1913, p. 32).]

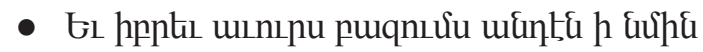
ntiqtinth, junnıgtiul ujunıhtiuntis huuu-

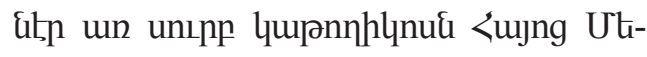

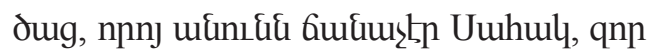

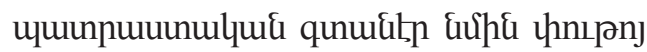
husuifiul (4np., 36): [And when he was wandering there for many days, he got up and came to the Holy Patriarch of the Great Hayk, known as Sahak, who was willing to quickly agree with him (Koryun, 1941, p. 36).]

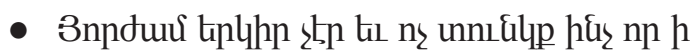

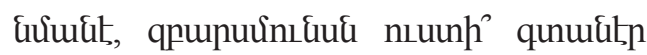

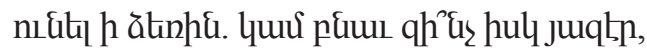
qh ufumunsep stis tisu the unuptiul (Gqu., 119): [When the earth and seedlings in it were not created where did he get the birches from, or what did he sacrifice when animals were not created yet (Eznik of Kolb, 1826, p. 119)?]

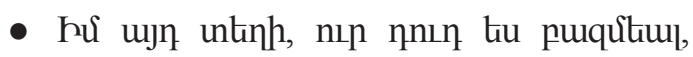
jnund luag ujnh, pnn tu ujnn puquitigujg, qh untinh uqqh uktinn wjn ltwul $t$. uшuш tipt ju2humphi hu huuhg, vitouutro untou hunntighg h pta (fnıq., 143): [That is my seat (the throne) where you are sitting now, get up, let me sit there because it's my dynasty's throne, or when I get to my country, you'll face my vengeance (Faustus of Byzantium, 1913, p. 143).]

The investigation of the linear patterns of these sentences as syntactic models has shown that these were the basis for the formation of sentences models of modern Armenian sentences.

Let us now consider the types of relations that exist amongst the primary sentence parts, between the primary and secondary sentence members in terms of linguistic determinism and how these relations are displayed in linear sentence patterns.

Language modelling of existing relation- 
ships between things and phenomena is done by means of equivalent linguistic symbols. Objects and actions are distinguished. Language reflects these realities through nouns and verbs. The noun is the linguistic (verbal) sign of the subject, and the verb is the action. At the same time, they have their own characteristics, attributes, which have their respective specifiers in language: adjectives supplement nouns, and adverbs supplement verbs.

What are the linguistic features of the subject and the action? What kinds of transactions occur in speech or in a sentence? The correlation of these sentence members and their reflections are conditioned by linguistic determinism. As chief sentence parts, the subject and predicate are in an equal relationship. This relationship is also reflected in the outside world where an object expressed by a subject and an attribute expressed by a predicate act as equivalents and equal realities. When the world is reflected through linguistic consciousness, the attribute expressed by the predicate becomes of primary importance. This notion is manifested in the linear plan of a sentence where the predicate is in the foreground compared with the other parts.

The examination of the syntactic sentence models of Old Armenian showcase that it is verb oriented more specifically with a syntax in which a predicate is placed in the foreground. ${ }^{3}$ Since subjects and predicates are inseparable, it is worth mentioning that in Old Armenian syntactic sentence models the subject mostly succeeds the predicate or is syntactically placed after it (Khachatryan \& Tosunyan, 2004, pp. 303-304).

Let's take a look at the language and sublexicon in the structural plan of the Old Arme-

This sentence structure later became the basis for formalistic grammatical doctrine, the representatives of which considered verbs as the sentences. nian sentences.

- 〈unipuná Upnuhuú quzu hıp tis tuntu,

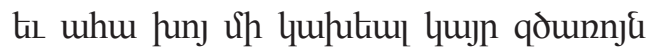
umptilum qtingtipurg. Gl qumg Lppuhuu

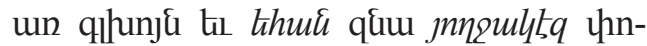

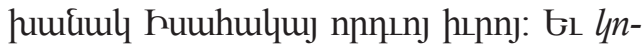

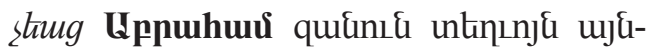
nphl Shp tiutu (Ofiun., hf, 13, 14): [Abraham looked up and there in a thicket he saw a ram caught by its horns. He went over and took the ram and sacrificed it as a burnt offering instead of his son. So Abraham called that place The LORD Will Provide (Genesis, 22: 13-14).]

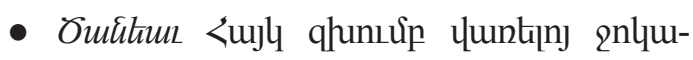

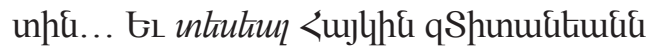

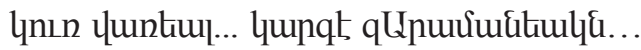
tı. quupnnu... p ăunuút (tunp., 36): [Recognized Hayk, the armed military group... And saw Hayk Titania severely armed... had Aramanyak and Kardos stand on his left (Khorenatsi, 1913, p. 36).]

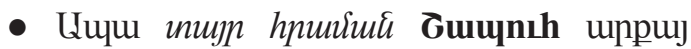

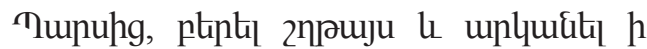
uщunuungú Unzuluu (fnıq., 143): [Then ordered Shapooh, the Persian king, to bring chains to throw around Arshak's neck (Faustus of Byzantium, 1913, p. 143).]

From the point of view of language perception, the grammatical role of the subject often becomes passive, and the predicted becomes absolutely dominant in the sentence:

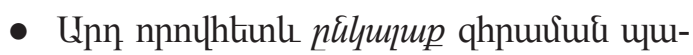

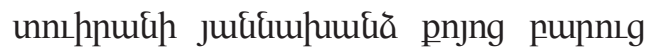

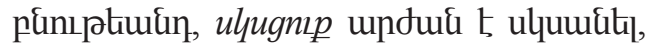

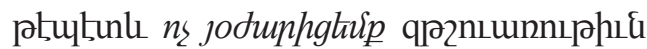
uqqhu vitinn nnpul (Gn., 5): [Now, because we accepted the order that comes from your not so jealous nature, we start from where it is worthwhile, though we 
would not agree on mourning the misery of our nation (Eghishe, 1957, p. 5).]

Objects and phenomena and their attributes are in a complementary relationship: linguistic determinism reflects their subordinate relationships by collocating the subject and predicate supplements in a reversed syntax in the linear sentence pattern.

Linguistic determinism and its comprehension have been adequately reflected in the Old Armenian sentence models: the subject supplements (noun or noun phrase) syntactically succeed it (Bagratuni, 1852, pp. 320-326).

- Lhuıunhl quu qtintighl, uitnăuinn $h \mathfrak{u}$, uhuıunhl quu qtinkghl, $\mathbf{U}_{2 \mathbf{p}}$ pn u-

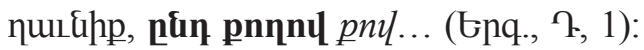
[Look at you - so beautiful, my dearest! Look at you - so beautiful! Your eyes are doves behind the veil of your hair! (Song of Songs 4: 1-16).]

- Tupuntiq thultiml, pnıjn hi hunud,

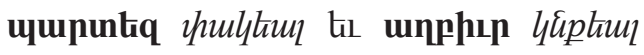
(Gnq., १, 12): [An enclosed garden is my sister, my bride; an enclosed pool, a sealed spring (Song of Songs 4:12).]

- Uuu lnstiug puquunnd Tupuhg Gu-

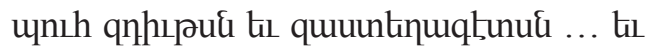

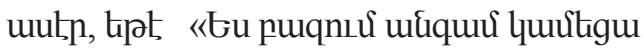

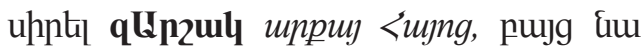
hưuul urumptiug qhu» (fnıq., 140): [Then the Persian king Shapooh called the magicians and astrologists and said: "I tried to love the Armenian king Arshak, for so many times, but he kept constantly insulting me" (Faustus of Byzantium, 1913, p. 140).] The action and its attributes are in a complementary relationship as well. This same subordinate relation is reflected in the linear plan of sentences. Comparison:

- 2huipn uщuzungtiúp qunkqulú, nр

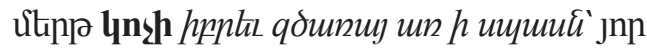

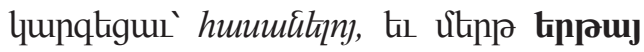
nont hpnks qunhnuntiuq, tis unuj untinh

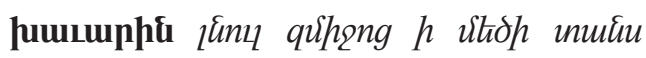
(Gqu., 15): [Why are we worshipping the sun, which like a servant is called to complete the service it is supposed to, and also it goes and hides like a scared creature letting the darkness fill its big house - the space (Eznik of Kolb, 1826, p. 15)?]

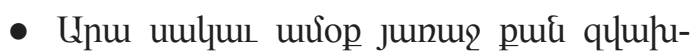

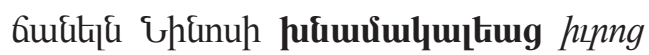

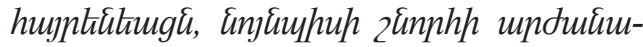

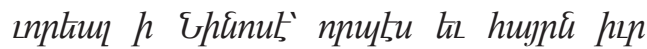
Lnmu (广unp., 48): [A few years before the death of Nynos, Ara reigned in his homeland, receiving the same honour as Nynos and his father Aram (Khorenatsi, 1913, p. 48).]

- Utipr zuujptn quiuptra hpntrs qoă pnzEmurn, vitip uuunqto qnits hpnter qu-

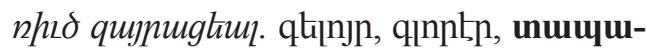
lbn tinlnhuih vinop (Gn., 16): [Sometimes it would shatter and roll up like a poisonous snake, then it would stretch out and rattle as an injured lion, crunching, rolling, and suffering from double-minded thoughts (Eghishe, 1957, p. 16).]

In syntactic models of Old Armenian, service words have foreground positions, and the premises and prefixes precede their direct object. Linguistic determinism explains this by the fact that the semantic load of the word is notified beforehand. On the other hand, the premises and the prefixes are preceded by the main parts of sentences.

The actions and their specifications expressed by verbs (attributes of place, time, reason, aim and etc.) which are articulated with preconception conjunctions, preceded their sup- 
plements in syntactic models of sentences.

So, let's take a look at the following sentences, where the established supplementary connectors preceded the supplements.

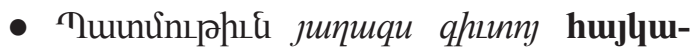
luú nupnцptiuा (4np., 22): [A story about the invention of the Armenian school (Koryun, 1941, p. 22).]

- 2h ứ' unung vikq luunuphughd (fnıq., 73): [Because without us, they will not be accomplished (Faustus of Byzantium, 1913, p. 73).]

- <uditiur ujunshtintis quuupna unnmupnj

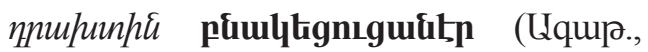
150): [Then he drove the men out and had them dwell outside the paradise (Agathangelos, 1909, p. 150).]

- <trotiup hpptis quuuphll qhtin kntry unzuungtía (Gqu., 107): [Horsemen, as people, are racing to hunt animals (Eznik of Kolb, 1826, p. 107).]

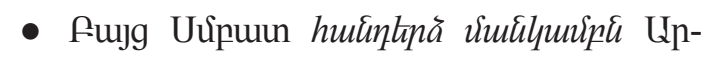

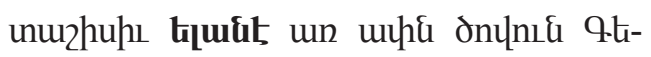
пưuuj (Hunp., 170): [But Smbat, along with Artashes's children, goes out to the shore of the Geghama Sea (Khorenatsi, 1913, p. 170).]

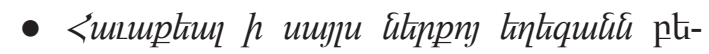
phuul punkighú h unju hnpu (Hunp., 296): [Under the reed, gathering in carriages and burying them in the same pit (Khorenatsi, 1913, p. 296).]

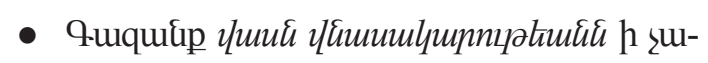
nt nuvitpt ununsts luundtighu (bqu., 146): [Wild animals, because of their harmfulness, are thought to be invented by some evil creator (Eznik of Kolb, 1826, p. 146).]

- 2nn h intinh Lnzulnikizy puquunptignjg $h$ ylinuy wzhumhhu <imng (Фunu., 19): [Which was turned into a king of the
Armenian world instead of the Arshakunis (Parpetsi, 1904, p. 19) ${ }^{4}$.]

The prefixes that express various grammatical relations, which are absolutely abstract forms (Abrahamyan, 1976, p. 227) not only towards their objects but also along with their objects have foreground place in the linear structure of a sentence. See:

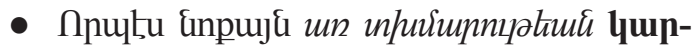

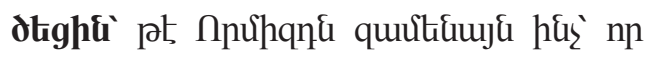
puph le qtintighl है unup (Gqu., 145): [Because of their stupidity, they thought that Wormizd created everything which is kind and beautiful (Eznik of Kolb, 1826, p. 145).]

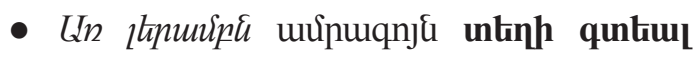
nunuptighr (Фupu., 74): [Finding a firm place on the mountain, they stopped (Parpetsi, 1904, p. 74).]

- Gu \&ưu phıр puphu hunphtiguj nnutu

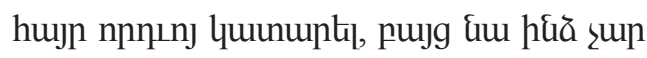
цuin pumin huunnjg (fnıq., 140): [I wanted to do good things for him as a father would do for his son, but he rewarded me with evil for good (Faustus of Byzantium, 1913, p. 140).]

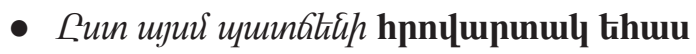
juzhuuphí <ujng (Gn., 10): [According to this copy, the decree reached the Armenian Land (Hayots Ashkharh) (Eghishe, 1957, p. 10$)^{5}$.]

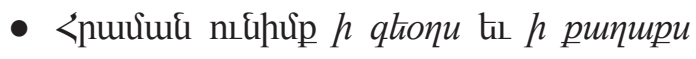
2huitı unnnızuiu (Gn., 70): [We have a decree to build fire worship places in the villages and in the cities (Eghishe, 1957, p. 70).]

4 The adverbial phrase "of the Armenian world" has post position order over the main part (king) of the sentence.

5 Phrases with the word according (prefix "Yst" ( .um) in Armenian) usually have reverse syntax. 
- sujdí tiu uuuú pn juzun undith, jujuर्u

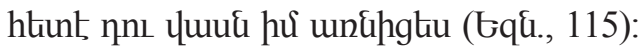
[So far I have been performing a sacrifice for you, from now on you will do it for me (Eznik of Kolb, 1826, p. 115).]

To sum up, the examination of the issues concerning the relationship between thinking and language modelling shows that linguistic models have a primary role in Old Armenian and determine the linguistic outlook and linguistic determinism of the society. On the other hand, as a synchronous maxim linguistic determinism can carry the stamp of foreign-language influences, preserving the essence and uniqueness of national thinking.

\section{REFERENCES}

Abrahamyan, A., (1976). Grabari dasy'nt'ac (Grabar Course, in Armenian). Yerevan: Luys. Agathangelos (1909). Agat'angeghay Patmut'yun Hayoc (History of Armenian by Agathangelos, in Armenian). Tpghis: Aragatip Mnatsakan Martrioseants.

Bagratuni, A., (1852). Hayere'n qerakanut'yun $i$ pe'ts zargaceloc (The Armenian Grammar for the Intelligent, in Armenian). Venice: Mkhit'aryan Miabanut'yun.

Brutian, G. A. $\left(1972^{\mathrm{a}}\right)$. Lingvisticheskoe modelirovanie deistvitel'nosti $i$ ego rol'v poznanii (Linguistic Modeling of Reality and its Role in Cognition, in Russian). The Issues of Philosophy, 10, 87-92.

Brutian, G. A. (1972 $\left.{ }^{\mathrm{b}}\right)$. P'ilisop'ayut'yun \& lezu (Philosophy and Language, in Armenian). Yerevan: Hayastan.

Eghishe, (1957). Eghishe'i vardapeti Vasn Vardanay ew Hayoc paterazmin (For Vardan and Armenian War by Eghishe Var- dapet, in Armenian). Yerevan: The Armenian SSR Academy of Sciences Publication.

Eznik of Kolb (1826). Eznkay Koghbacwoy Bagrewanday episkoposi Eghc' aghandoc (Against the Sects by Eznik of Kolb, in Armenian). Venice: Mkhit'aryan Miabanut'yun.

Faustus of Byzantium (1913). P'awstosi Biwzandacwoy Patmut'yun Hayoc (History of Armenian by Faustus of Byzantium, in Armenian). Tip'lis: G.Galstean.

Hayrapetyan, S. (2005). Grabari sharadasut'yuny' (The Word Order of Grabar, in Armenian). Yerevan: Gitut'yun.

Hovhannisyan, H. H. (2009). P'astarkman harcery' hay p'ilisopayakan mtqi patmut'yan hamateqstum (The Issues of Argumentation in the Context of the History of Armenian Philosophical Thought, in Armenian). Yerevan: International Academy for Philosophy Publication.

Hovhannisyan, H. H. (2017). Problems of Argumentation in Medieval Armenian Philosophy. WISDOM, 1(8), 81-94. doi:10.24234/wisdom.v8i1.177.

Jahukyan, G., (1989). Jhamanakakic hayoc lezvi imastabanut'yun \& barakazmut'yun (Semantics and Word-Formation of Modern Armenian Language, in Armenian). Yerevan: The Armenian SSR Academy of Sciences Publication.

Khachatryan, L., \& Tosunyan, G. (2004). Grabari dasagirq (Grabar Textbook, in Armenian). Yerevan: Zangak-97.

Khorenatsi, M., (1913). Movsisi Khorenacwoy Patmut'yun Hayoc. (History of Armenia by Movses Khorenatsi, in Armenian). Tpghis: Aragatip Mnatsakan Martiroseants. 
Kodukhov, V. N., (2013). Obshchee yazykoznanie (General Linguistics, in Russian). Moscow: Book House "LIBROKOM".

Kopnin, P. V., (1968). Problemy teorii poznaniya $i$ logiki (Problems of Theory of Knowledge and Logic, in Russian). In The Materials for XIV International Philosophical Congress (Vol. I). Moscow.

Koryun, (1941). Varq Mashtotsi (Life of Mashtots, in Armenian). Yerevan: Haypethrat.

Lingvisticheskii entsiklopedicheskii slovar' (Linguistic Encyclopedic Dictionary, in Russian). (1990). Moscow: Soviet Encyclopedia.

Muradyan, G. (2010). Hunabanut'yunnery' dasakan hayerenum (Greecologies in Classical Armenian, in Armenian). Yerevan: Nairi.

Parpetsi, (1904). Ghazaray P'arpecwoy Patmut'yun Hayoc ew T'ught' ar Vahan Mamikonean (History of Armenia and a Letter to Vahan Mamikonyan by Ghazar
Parpetsi, in Armenian). Tpghis, Aragatip Mnatsakan Martiroseants.

Pavilenis, R. I., (1983). Problema smysla: Logiko-funktsional'nyi analiz yazyka (The Problem of Sense: Logico-Functional Analysis of the Language, in Russian). Moscow: Thought.

Pishchalnikova, V. A., \& Sonin A. G. (2017). Obshchee yazykoznanie (General Linguistics, in Russian). Moscow: R. Valent.

Tarasov, E. F., (2000). Yazykovoe soznanie perspektivy issledovaniya (Language Cognition - Research Perspectives, in Russian). In Language Cognition: Content and Functioning: the Materials of XIII International Symposium on Psycholinguistics and Theory of Communication (pp. 2-4). Moscow: IYA RAN.

Whorf, B. L., (1966). Language, Thought and Reality. Massachusets Institute of Technology. 